\title{
Periodontal Pocket
}

National Cancer Institute

\section{Source}

National Cancer Institute. Periodontal Pocket. NCI Thesaurus. Code C62547.

An abnormal deepening of a ging ival sulcus associated with destruction of the supporting periodontal tissue. 